\title{
Thermal and Photochemistry of Methyl Iodide on Ice Film Grown on $\mathrm{Cu}(111)$
}

\author{
Youngku Sohn and John M. White ${ }^{\dagger, a}$ \\ Department of Chemistrv, Yeungham University, Gveongsan. Gveongbuk 712-749. Korea \\ 'E-mail: youngkusohnawnackr \\ Center for Materials Chemistrv. Department of Chemistrvand Biochemistrv. The University of Texas at tustin, \\ Texas 78712, USt \\ Recerved April 20,2009, Accepted Hav 9, 2009
}

\begin{abstract}
Thenmal and photochemistry of methyl iodide $\left(\mathrm{C}_{3} \mathrm{I}\right)$ adsorbed on $\mathrm{D}_{2} \mathrm{O}$ ice film on $\mathrm{Cu}(1 \mathrm{l})$ at $100 \mathrm{~K}$ were studied using tenperature-programned desoption (TPD) time-of-flight mass spectrometry (TOF-MS), X-ray and ultráviolet photoelectron spectroscopies. On the basis of TPD, multilayer and monolayer $\mathrm{CH}_{3} \mathrm{I}$ molecules desorb from $\mathrm{D}_{1} \mathrm{O}$ ice layer at 120 and $130 \mathrm{~K}$, respectively. Photo-irradiation at $100 \mathrm{~K}$ exhibits dramatic changes in the TPD and I $3 \mathrm{~d}_{5: 2}$ XPS of $\mathrm{CH}_{3} \mathrm{I}$ on ice film, due to a dramatic dissociation of $\mathrm{CH}_{3} \mathrm{I}$. The dissociation is likely activated by solvated electrons transferred from the metal substrate during photo-irradiation. No other photo-initiated reaction products were found within our instrumental detection limit. During photo-irradiation, the $\mathrm{CH}_{3} \mathrm{I}_{3} \mathrm{CH}_{3}$ and $\mathrm{I}$ could be trapped (or solvated) in ice fïln by rearrangement (and self-diffusion) of water molecules. A newly appeared parent molecular desorption peak at $145 \mathrm{~K}$ is attributed to trapped $\mathrm{CH}_{3} \mathrm{I}$. In addition, the $\mathrm{CH}_{3}$ and I may diffuse through ice and chemisorb on Cu(111), indicated by TPD and I 3 $\mathrm{d}_{5: 2}$ XPS taken with photo-irradiation time, respectively. No molecular ejection was found during photo-iradiation at $100 \mathrm{~K}$. The work functions for $\left.\mathrm{CH}_{3} \mathrm{I} / \mathrm{Cu}(1] 1\right), \mathrm{D}_{2} \mathrm{O} / \mathrm{Cu}$ (111) and $\mathrm{CH}_{3} \mathrm{I} / \mathrm{D}_{2} \mathrm{O} / \mathrm{Cu}(111)$ were all measured to be about $3.9 \mathrm{eV}, 1.0 \mathrm{eV}$ downward shift from that of clean $\mathrm{Cu}(111)$.
\end{abstract}

Key Wonds: Temperature-programmed desorption. X-ray photoelectron spectroscopy. Photo-dissociation, Solvated electron, Diffusion

\section{Introduction}

Understanding heterogeneous catalysis reactions of molecules on metal cataly sts is of very importance fundamentally and industrially. Uncountable researches have been performed to elucidate specific or general reaction processes for molecules of interest. ${ }^{1.4}$ Among the molecules. halocarbon compounds have been employed to understand reactions of alkyl groups adsorbed on a catalytic substrate from an industrial point of view, ${ }^{1 \cdot 3}$ also to tract reactions between stratospherically (or environmentally) important molecules and frozen water molecules. ${ }^{5-8}$ Stratospheric ozone depletion has been understood through halogen radical-related (e.g. chlorofluorocarbons) reaction chemistry. ${ }^{9.15}$ Envirommentally. for the photo-initiated (e.g. by sunlight) chemistry of organic molecules the role of ice (or snow) has been studied deeper and broader. ${ }^{11}$ This includes uptake of organic compounds by ice and release (or desorption) of the molecules (or other thermal and photo-induced reaction products) from ice by temperature rise. When organic molecules in (or on) ice are irradiated by UV photons it is known that solvated electrons in ice play a significant role in the dissociation of the molecules.

The aim of this research is to better understand the role of ice in the dissociation. desorption of halocarbon compounds. and the behaviors (e.g. diffusion and solvation) of the molecules including halogen radicals. Assisted by temperature programmed desorption. $\mathrm{X}$-ray and ultra-violet photoelectron spectroscopies. we have studied $\mathrm{CH}_{3} \mathrm{I}$ which has widely been

${ }^{2}$ Deceased August 31, 2007 employed for understanding (heterogeneous) catalytic photochemical and thermal reaction processes of halocarbons adsorbed on a metal substrate. ${ }^{12.17}$ Because the initial therntal or photo-dissociation channel is a breakage of $\mathrm{C}-\mathrm{I}$ bond. and no reformation of $\mathrm{C}-\mathrm{I}$ bond occurs it is possible to separately elucidate the behaviors of $\mathrm{CH}_{2}$ and $\mathrm{I}$.

\section{Experimental Section}

The experiments were performed in an ultra-high vacuum chamber with a base pressure of about $4 \times 10^{-16}$ Torr. The $\mathrm{Cu}$ (111) single cry stal disc ( $13 \mathrm{~mm}$ diameter and $2.5 \mathrm{~mm}$ thick, MaTeck) was cleaned by several cycles of $\mathrm{Ar}^{+}$ion sputtering followed by annealing at $850 \mathrm{~K}$. The cleanliness was checked using an Auger electron spectrometer or a X-ray photoelectron spectrometer (XPS). The crystal was resistively heated using a tungsten wire. or cooled to $100 \mathrm{~K}$ by contacting with a liquid nitrogen cooled holder. The temperature was measured using a cluromel-alumel thernnocouple. Methyl iodide $\left(\mathrm{CH}_{3} \mathrm{I}\right.$. Aldrich) and $\mathrm{D}_{2} \mathrm{O}$ (Cambridge Isotope. 99.9\%) were degassed by repeated freeze-pump-thaw cycles. The adsorbates were dosed through a stainless steel tube connected to a leak valve at a substrate temperature of $100 \mathrm{~K}$. The open end of the tube was about $4 \mathrm{~cm}$ away from the $\mathrm{Cu}(111)$ surface. In this paper, all the dosages were reported in langmuirs ( $\mathrm{L}=1 \times 10^{-6}$ torr $\left.\cdot \mathrm{s}\right)$ without sensitivity correction of the ion gauge for the adsorbate. For $\mathrm{CH}_{3}\left[(1.0 \mathrm{~L}) / \mathrm{D}_{2} \mathrm{O}(1.0 \mathrm{~L}) / \mathrm{Cu}(111)\right.$ sample, $1.0 \mathrm{~L}$ of $\mathrm{D}_{2} \mathrm{O}$ was first dosed on $\mathrm{Cu}(111)$ at $100 \mathrm{~K}$. and then $1.0 \mathrm{~L}$ of $\mathrm{CH}_{3} \mathrm{I}$ was dosed on top of the $\mathrm{D}_{2} \mathrm{O}$ layer. Temperature-programmed desorption (TPD) spectra before and after photo- 
irradiation were taken using a time-of-flight mass spectrometer (TOF-MS) at a temperature ramp rate of $2 \mathrm{~K} / \mathrm{s}$. A $100 \mathrm{~W} \mathrm{Hg}$ lamp (Oriel) was used for photo-irradiation to the sample at $100 \mathrm{~K}$. The XPS measurements were carried out using a Perkin-Elmę șystem with a Mg K $\alpha$ ( $1253.6 \mathrm{eV}) \mathrm{X}$-ray source and a hemispherical energy analyzer. Ultraviolet photoelectron spectroscopy (UPS) spectra were taken using a photon energy of $21.2 \mathrm{eV}$ (He I). A bias of $-5.0 \mathrm{~V}$ was applied to the substrate during the UPS.

\section{Results and Discussion}

Figure 1 shows the 15 amu TPD profiles for $\mathrm{CH}_{3} \mathrm{I}(1.0 \mathrm{~L}) /$ $\mathrm{D}_{2} \mathrm{O}(1.0 \mathrm{~L}) / \mathrm{Cu}(11 \mathrm{l})$ at $100 \mathrm{~K}$ before and after 10 and $30 \mathrm{~min}$ photo-irradiation. Before the data is mentioned in detail. we will briefly discuss the TPD (not shown) of $\mathrm{CH}_{3} \mathrm{I}$ dosed on a bare $\mathrm{Cu}(111)$ at $100 \mathrm{~K}$. A broad $16 \mathrm{amu}\left(\mathrm{CH}_{+}^{+}\right)$peak at $460 \mathrm{~K}$ is attributed to a major thermal product. methane $\left(\mathrm{CH}_{4}\right)$. A broad $15 \mathrm{amu}\left(\mathrm{CH}_{3}{ }^{+}\right)$TPD peak at $460 \mathrm{~K}$ with an intensity of $0.9 \times I_{\text {lsamu }}$ is due to a fragmentation of $\mathrm{CH}_{4}$. Two $15 \mathrm{amu}$ TPD peaks were found at 120 and $140 \mathrm{~K}$. The former is attributed to multilayer desorption of $\mathrm{CH}_{3} \mathrm{I}$. The latter is due to methyl radical ejection during the thermal dissociation of $\mathrm{CH}_{3} \mathrm{I}$ into $\mathrm{CH}_{3}$ and $\mathrm{I}$ at $140 \mathrm{~K}$. The atomic iodine strongly chemisorbs on $\mathrm{Cu}(111)$ while the $\mathrm{CH}_{3}$ radical either ejects into gas phase. or adsorbs on $\mathrm{Cu}$ when an empty adsorption site is available. The adsorbed $\mathrm{CH}_{3}$ form mainly $\mathrm{CH}_{4}$ and minor ethylene. or desorbs at $460 \mathrm{~K}$. The chemisorbed I desorbs at above 950 $\mathrm{K}$. "The details of thermal chemistry of $\mathrm{CH}_{3} \mathrm{I}$ on Cu substrate are described in elsewhere. ${ }^{16.1 \%}$

In Figure 1, two 15 amu peaks are seen at 120 and $130 \mathrm{~K}$ for the sample without photo-irradiation. The $1+2\left(\mathrm{CH}_{3} \mathrm{I}^{+}\right)$and $127 \mathrm{amu}\left(\mathrm{I}^{+}\right)$TPDs (not shown) exhibit the same desorption profiles as the 15 amu TPD. The lower and higher temperature TPD peaks are attributed to multilayer and monolayer desorption of parent $\mathrm{CH}_{3} \mathrm{I}$ from $\mathrm{D}_{2} \mathrm{O}$ ice film. respectively. The multilayer desorption position at $120 \mathrm{~K}$ is the same as that observed for multilayer $\mathrm{CH}_{3} \mathrm{I}$ on bare $\mathrm{Cu}(1 \mathrm{Il})$ as expected. For the peak at $130 \mathrm{~K}$, it is estimated that $I_{1 \text { samu }} / I_{1+2 \text { amu }}\left(\mathrm{CH}_{3}{ }^{+} / \mathrm{CH}_{3} \mathrm{I}^{+}\right)=0.76$ and $I_{1}$ sam $/ I_{1 \text { sam }}\left(\mathrm{I}^{+} / \mathrm{CH}_{3} \mathrm{I}^{-}\right)=0.5$. based on the relative TPD intensity. The 15 and 127 amu are mainly due to fragmentations of the parent molecule ( $1+2 \mathrm{amu})$. Other plausible desorption products were examined: $\mathrm{CH}_{3} \mathrm{OH}(29.31$ and $32 \mathrm{amm})$. acetone ( 43 and 58 amu). acetic acid ( 43.45 and $60 \mathrm{amu}$ ), formic acid (29 and $46 \mathrm{amu}$ ) and other I-containing species (e.g. I $\mathrm{I}_{2}$ ). but no clear evidence of these products was found within our instrumental detection limit. For the thermal desorption profile of $\mathrm{D}_{2} \mathrm{O}$ (not shown), the desorption begins at around $140 \mathrm{~K}$ and shows a maximum intensity at $166 \mathrm{~K}$. We assume that the ice film on $\mathrm{Cu}$ is amorphous because $\mathrm{D}_{-} \mathrm{O}$ was dosed at 100 $\mathrm{K}^{13}$

Upon $5 \mathrm{~min}$ photo-irradiation. the desorption peak at $130 \mathrm{~K}$ is reduced by $17 \%$. Upon 30 min photo-irradiation. the peak is dramatically reduced by about $92 \%$. In addition. a new peak appears at $145 \mathrm{~K}$. It is estimated that $I_{1 \text { saruu }} / I_{14 \text { Iamu }}\left(\mathrm{CH}_{3} / \mathrm{CH}_{3} \mathrm{I}\right)=$ 1 and $I_{13 \text { and }} / I_{\text {lizamu }}\left(1 / \mathrm{CH}_{3} \mathrm{I}\right)=0.54$ for the two peaks at 130 and $145 \mathrm{~K}$. Compared to $\mathrm{CH}_{3}$ I without photo-irradiation, the $I_{15 \text { amu }} / I_{14 \text { amu }}$ ratio is increased from 0.76 to $\mathrm{L}$. This indicates

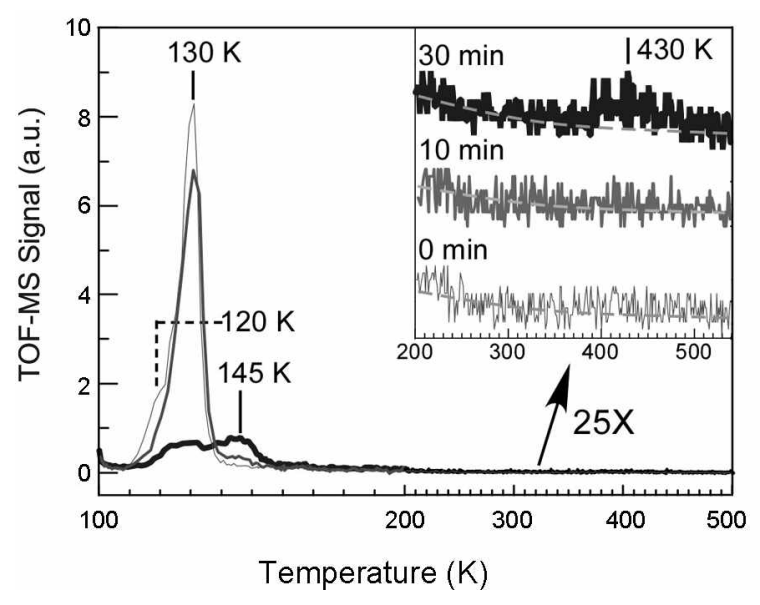

Figure 1. 15 amu TPD profiles with UV photo-irradiation time $(0$, 10 , and $30 \mathrm{~min})$ for $\mathrm{CH}_{3} \mathrm{I}(1.0 \mathrm{~L}) / \mathrm{D}_{3} \mathrm{O}(1.0 \mathrm{~L}) / \mathrm{Cu}(111)$ at $100 \mathrm{~K}$. Inset shows magnitied TPD protiles, ranging trom 200 to $540 \mathrm{~K}$

that $\mathrm{CH}_{3}$ radical ejection is enhanced relative to the parent molecule desorption. It seems that $\mathrm{CH}_{3}$ radicals formed by photo-dissociation of $\mathrm{CH}_{3} \mathrm{I}$ are trapped (or solvated) in ice, and they desorb during TPD. discussed further later.

To check the origin of the desorption peaks at 130 and 145 $\mathrm{K}$. TPD for $\mathrm{D}_{2} \mathrm{O}(1.0 \mathrm{~L}) / \mathrm{CH}_{3} \mathrm{I}(1.0 \mathrm{~L}) / \mathrm{Cu}(111)$ at $100 \mathrm{~K}$ was performed. For the sample. $\mathrm{CH}_{3} \mathrm{I}$ was dosed first on top of a bare $\mathrm{Cu}(111)$ substrate, and then $\mathrm{D}_{2} \mathrm{O}$ was dosed to cover $\mathrm{CH}_{3} \mathrm{I}$. The $1+2$ anu TPD profile (not shown here) exhibits two peaks at 136 and $150 \mathrm{~K}$. with an intensity ratio of $I_{136 K} I_{150 K}=$ 4/6. The desorption positions are very similar to the two peaks (Figure 1) obsened after $30 \mathrm{~min}$ photo-irradiation. For $\mathrm{D}_{2} \mathrm{O} / \mathrm{CH}_{3} \mathrm{I} / \mathrm{Cu}(111)$, three plausible geometries of $\mathrm{CH}_{3} \mathrm{I}$ are i) chemisorbed directly on $\mathrm{Cu}(111)$, ii) covered by $\mathrm{D}_{2} \mathrm{O}$. iii) and exposed on the surface of $\mathrm{D}_{2} \mathrm{O}$ ice film. Because chemisorbed $\mathrm{CH}_{3} \mathrm{I}$ do not desorb from $\mathrm{Cu}$ surface ${ }^{16,1 ?}$ the two TPD peaks correspond to the latter two plausible geometries (covered by and exposed on the ice film). It is more appropriate that the higher temperature peak at $150 \mathrm{~K}$ is assigned to $\mathrm{CH}_{2} \mathrm{I}$ covered by ice film. The peak at $136 \mathrm{~K}$-close to $130 \mathrm{~K}$ seen in Figure $\mathrm{l}-$ is then attributed to $\mathrm{CH}_{2} \mathrm{I}$ on the ice film. Because the peak at $145 \mathrm{~K}$-observed after 30 nin photo-irmadiation-is very close to $150 \mathrm{~K}$ the adsorption geonetries of $\mathrm{CH}_{3} \mathrm{I}$ for the two peaks seem to be very similar. In other words, for $\mathrm{CH}_{3} \mathrm{~L} / \mathrm{D}_{2} \mathrm{O} / \mathrm{Cu}(\mathrm{ll} \mathrm{l})$ $\mathrm{CH}_{s}$ I diffuses into ice film by rearrangement (and self-diffusion) of water molecules during photo-iradiation. and desorbs at $145 \mathrm{~K}$ during TPD. It was found that the desorption position of $\mathrm{CH}_{3} \mathrm{I}$ depends on the cry stallinity of ice film. ${ }^{19}$ However we have no evidence of change in the crystallinity of the ice film before and after photo-irradiation. Interestingly. for $\mathrm{CH}_{3} \mathrm{I}$ on 5 monolayers (mL) of amorphous $\mathrm{D}_{2} \mathrm{O}$ grown on $\mathrm{Ru}(000 \mathrm{l})$ at $50 \mathrm{~K}$. Perry et al. found that $\mathrm{CH}_{3} \mathrm{I}$ desorption dominates at $130 \mathrm{~K}$ for $0.3 \mathrm{~mL}$ coverage of $\mathrm{CH}_{3} \mathrm{I}$ while at $145 \mathrm{~K}$ for higher coverages $\left(>1 \mathrm{~mL}\right.$ ) of $\mathrm{CH}_{2} \mathrm{I}$. For $3.0 \mathrm{~mL} \mathrm{CH}_{2} \mathrm{I}$ on $\mathrm{D}_{2} \mathrm{O}$ ice film with increasing electron beam irradiation time, they found that the dominant peak at $145 \mathrm{~K}$ becomes weaker while the peak at $130 \mathrm{~K}$ becomes stronger and broadens. Further irradiation makes the peak at $130 \mathrm{~K}$ disappear. Their results are in contrast with our TPD shown in Figure 1. 

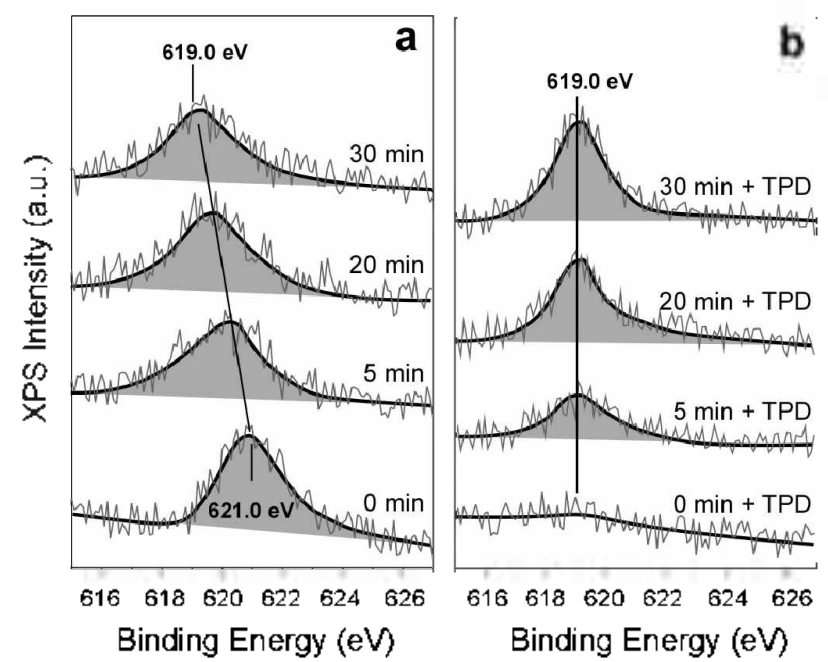

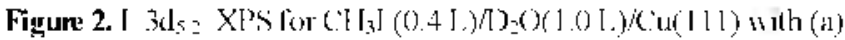
photo-irradiation (at $100 \mathrm{~K}$ ) time, (b) phere-irradiation at $100 \mathrm{~K}$ followed by TPI from 1000 to $800 \mathrm{~K}$

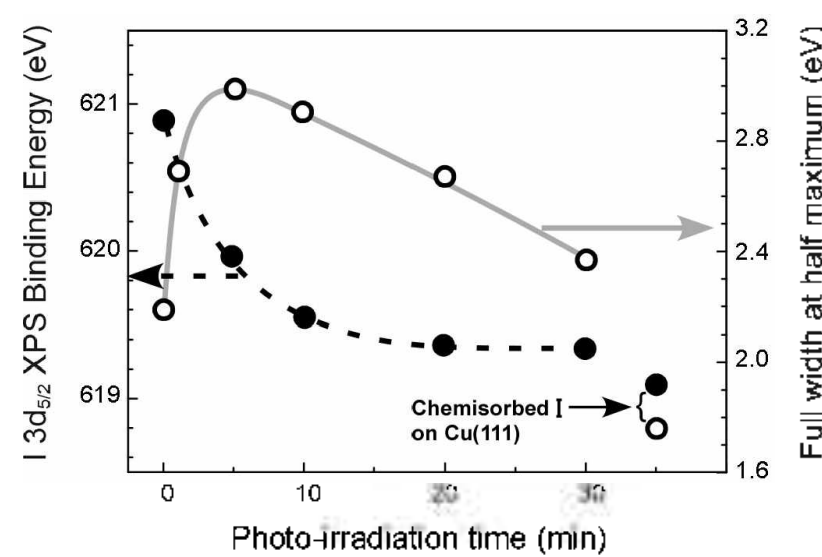

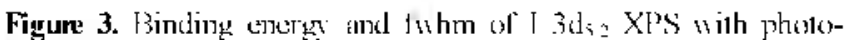

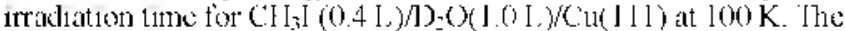

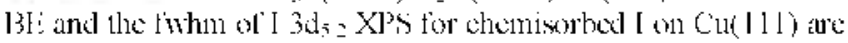
also displar wol

In the inset of Figure 1. for the 30 min photo-irradiated sample a broad 15 amu TPD signal is secn at $430 \mathrm{~K}$. Although the peak is not strong it clearly appears above the background. Because the water desorption is completely finished below $300 \mathrm{~K}$, the 15 amu peak could be due to desorption of $\mathrm{CH}_{4}$ and/or $\mathrm{CH}_{3}$ from bare $\mathrm{Cu}^{16.17}$ No 127 and 142 amu peaks were found at $430 \mathrm{~K}$ indicating no desorption of parent $\mathrm{CH}_{3} \mathrm{l}$ at 430 $\mathrm{K}$. Because the peak at $430 \mathrm{~K}$ is due to chemisorbed $\mathrm{CH}_{3}$ on

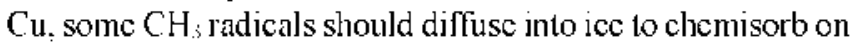
$\mathrm{Cu}$ during photo-irradiation at $100 \mathrm{~K}$ and/or TPD. Because the peak at $430 \mathrm{~K}$ is weak we could assume that $\mathrm{CH}_{\text {i ditlusion is }}$ not that significant, but detectable.

XPS measurements were performed for both cuantitative and more qualitative analyses. Figure 2 displays I $3 \mathrm{~d}_{2}$ XPS for $\mathrm{CH}_{3} \mathrm{I}(0.4 \mathrm{~L}) / \mathrm{D}_{3} \mathrm{O}(1.0 \mathrm{~L}) / \mathrm{Cu}(111)$ at $100 \mathrm{~K}$ with (a) photoirradiation time at $100 \mathrm{~K}$ and (b) photo-irradiation time followed by TPD to $800 \mathrm{~K}$. Figure 3 displays the XPS BE and the full width at half-maximum (fwhm) of $\mathrm{CH}_{i} \mathrm{I}(0.4 \mathrm{~L}) / \mathrm{D}_{2} \mathrm{O}$ $(1.0 \mathrm{~L}) / \mathrm{Cu}(111)$ with photo-irradiation time at $100 \mathrm{~K}$. The

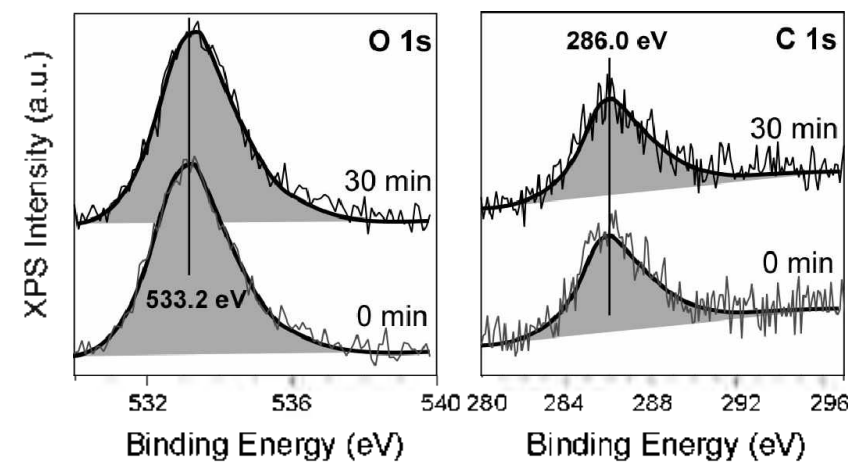

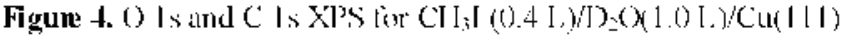
before and at ter $30 \mathrm{~min}$ pholo-inadiation at $100 \mathrm{~K}$

I $3 \mathrm{~d}_{5}=\mathrm{XPS} \mathrm{BE}$ and the fwhm for chemisorbed I on Cu(111) are $619.0 \mathrm{cV}$ and $1.7 \mathrm{eV}$. respectively. The chemisorbed $\mathrm{I}$ on $\mathrm{Cu}(1 \mathrm{ll})$ was achicred br annealing of I $.0 \mathrm{~L} \mathrm{CH}_{3} \mathrm{I}$ on $\mathrm{Cu}(\mathrm{III})$ to $800 \mathrm{~K}^{10: 17}$ In Figure 2a before photo-irradiation, the $13 \mathrm{~d}_{5}=$ XPS peak is positioned at about $621.0 \mathrm{cV}$ with a fwhm of 2.2 eV. Upon 5 min photo-irradiation. the XPS peak is dramatically. changed: the BE is decreased by $\mathrm{I} \mathrm{cV}$ and the fwhm is broadened to $3.0 \mathrm{cV}$. As the photo-irradiation time increases further the $\mathrm{BE}$ is further decreased to near $619.0 \mathrm{eV}$ while the fwhm becomes narrower. Because $\mathrm{CH}_{3}$ I dissociales to $\mathrm{CH}_{3}$ and I by photo-irradiation the increase in fwhm of I $3 d_{5}$ XPS is due to XPS signals from boht un-dissociated and dissociated $\mathrm{CH}_{3} \mathrm{I}$. Upon further photo-irradiation. the dissociated $\mathrm{CH}_{3} \mathrm{I}$ becomes dominant to decrease in fwhm. The decrease in BE of I $3 d_{5}=$ XPS with increasing photo-irradiation time could be due to an increase in sols ated I, I radical, and/or chemisorbed I on Cu. Figure $2 b$ contains some information on how the $\mathrm{l}$ radicals (or solvated l ) behave. Without photo-irradiation, $\mathrm{CH}_{3}$ I completely desorbs from Cu. and no I 3d 2 XPS peak is seen after TPD to $800 \mathrm{~K}$. Afier $5 \mathrm{~min}$ photo-irradiation at $100 \mathrm{~K}$ followed by TPD to $800 \mathrm{~K}$ a I $3 \mathrm{~d}_{2}$ XPS pcak appears at $619.0 \mathrm{eV}$, with a fwhm of $1.7 \mathrm{cV}$. As the photo-irradiation time increases the I $3 \mathrm{~d}=$ : XPS peak becomes stronger, with no change in BE. The $\mathrm{BE}$ and the fwhm are nearly the same as those for chemisorbed I on Cu( 111 ). This indicates that the I radicals (or solvated I ) do not desorb. instead ther chemisorb on the $\mathrm{C}_{\mathrm{u}}$ surface. For chemisorption, they should diffuse into ice film toward $\mathrm{Cu}$ surface during photo-irradiation at $100 \mathrm{~K}$ and/or TPD. The belavior of iodine diffusion is indicated by the gradual decrease in BE to $619.0 \mathrm{cV}$ (the I $3 \mathrm{~d}_{3}$ XPS BE for chemisorbed I on $\mathrm{Cu}$ ) with increasing photo-irradiation time at $100 \mathrm{~K}$ (Figure 2a).

Figure 4 shows $\mathrm{O}$ Is and $\mathrm{C}$ Is XPS for $0.4 \mathrm{LCH}_{3} \mathrm{I}$ adsorbed on $\mathrm{D}_{2} \mathrm{O}$ iec film before and after 30 min photo-iradiation at $100 \mathrm{~K}$. The intensities and the $\mathrm{BE}$ positions of the $\mathrm{O} \mathrm{Is}(\mathrm{BE}=$ $533.2 \mathrm{cV})$ and the $\mathrm{C}$ Is $(\mathrm{BE}=286.0 \mathrm{cV})$ XPS show negligible changes eren after 30 min photo-irradiation. This indicates that no other chemical species form and/or desorb from the surlace during photo-irradiation at $100 \mathrm{~K}$. For tent-buty l iodide adsorbed on ice film. Sohn et al. found that the C Is XPS peak of the sample was signilicantly decreased by about $40 \%$ after only 5 min photo-irradiation at $100 \mathrm{~K}$. Ther attributed this to facile cjection of reaction products (c.g. isobutene and iso- 
butene) at $100 \mathrm{~K} .^{2(1}$ In Figure 1, the 15 amu $\left(\mathrm{CH}_{3}^{-}\right)$TPD peak is dramatically decreased after $30 \mathrm{~min}$ photo-irradiation at $100 \mathrm{~K}$. If the decrease in intensity is solely due to molecular ejection during photo-irradiation, the C ls XPS peak should be decreased. but the peak shows no change. This indicates that the dissociated products stay on (or in) the ice film by trapping and solvation. For $0 .+\mathrm{L} \mathrm{CH}_{3} \mathrm{I}$ on bare $\mathrm{Cu}(111)$. the intensities and the $\mathrm{BE}$ positions of $\mathrm{C} 1 \mathrm{~s}(\mathrm{BE}=288.0 \mathrm{eV})$ and I $3 \mathrm{~d}_{\mathrm{s}}(\mathrm{BE}=620.0 \mathrm{eV}$ ) XPS (not shown) show no change before and after photo-irradiation. The results indicate that $\mathrm{CH}_{3} \mathrm{I}$ on bare $\mathrm{Cu}(111)$ is nearly intact by photo-irradiation. compared to $\mathrm{CH}_{3} \mathrm{I}$ on ice.

It has been known that solvated electrons $\left(\mathrm{e}_{\mathrm{z}}^{-}\right)$play a crucial role in the dissociation of halocarbon compounds adsorbed on ice. ${ }^{6.11 . .1}$ For the dissociation of $\mathrm{CH}_{3} \mathrm{I}$ on ice film by photons with energies up to $-5 \mathrm{eV}$, the following reaction is proposed.

$$
\begin{aligned}
& \mathrm{e}_{s}^{-}+\mathrm{CH}_{3} \text { /ice } \rightarrow \mathrm{CH}_{3} \mathrm{I}^{*} \rightarrow \mathrm{CH}_{3}^{*}+\mathrm{I}^{-} \\
& \mathrm{I}^{-}+\mathrm{CH}_{3}^{*} \rightarrow \mathrm{I} \text { (trap. sol) }+\mathrm{e}_{*}^{-}+\mathrm{CH}_{3} \text { (trap. sol), } \\
& \text { or } \rightarrow \mathrm{I}^{-} \text {(trap. sol) }+\mathrm{CH}_{3} \text { (trap. sol) }
\end{aligned}
$$

In the reaction. the $\mathrm{C}-\mathrm{I}$ bond of transient $\mathrm{CH}_{3} \mathrm{I}^{-*}$ breaks into $\mathrm{CH}_{3}$ and $\mathrm{I}^{-}$via dissociative electron capture process of $\mathrm{CH}_{3} \mathrm{I}^{6: 1}$ The $\mathrm{I}^{-}$anion either back-transfers an electron into ice or not. and then the I anion (or radical) is solvated(sol)/trapped (trap) in ice film. ${ }^{6.1}$ The $\mathrm{CH}_{3}$ radical may also be trapped/sol $\mathrm{e}_{?}^{-}$vated in ice film. During the time a structural rearrangement (and self-diffusion) of water molecules may also occur. The water molecules should rearrange to minimize the energy potential when the enviromments of water molecules are changed upon forming new species (e.g. $\mathrm{CH}_{3}$ and I from $\mathrm{CH}_{3} \mathrm{I}$ ) on ice film. Because the thickness of $1.0 \mathrm{~L} \mathrm{D}_{2} \mathrm{O}$ is not that thick (about 2.5 monolayers) ${ }^{\hat{2}}$ if the $\mathrm{I}^{-}$anion (or I radical) moves further toward $\mathrm{Cu}$ during the water rearrangement and the solvation process, and is in the range of electronic coupling with $\mathrm{Cu}$. the $\mathrm{I}^{-}$anion (or I radical) is driven to chemisorb on the surface. The I $3 \mathrm{~d}_{52}$ XPS BE shift (Figure 2a) with photoirradiation time could indicate chemisorption of iodine on $\mathrm{Cu}$. For $\mathrm{CH}_{3} \mathrm{I}: \mathrm{H}_{2} \mathrm{O}$ mixed matrix. Pery et al found a similar $\mathrm{I} 3 \mathrm{~d}_{5} \mathrm{~s}$ XPS BE shift to a lower BE position from $62+$ to $622.5 \mathrm{eV}$ after 3 hour X-ray irradiation. They proposed that the BE shift to a lover BE was due to solvated $I^{-}$anion. ${ }^{6}$ In addition to adsorption of residual water molecules on $\mathrm{CH}_{3} \mathrm{I}$ at $100 \mathrm{~K}$. we also checked diffusion of the molecules by self-diffusion of water molecules at $100 \mathrm{~K}$ without photo-irradiation. However. we found no indication of these phenomena.

Finally, in the system studied here. the solvated electrons in ice film are likely the electrons transferred from the $\mathrm{Cu}$ metal substrate during photo-irradiation ${ }^{33,24}$ The work function for $\mathrm{D}_{3} \mathrm{O} / \mathrm{Cu}(\mathrm{Ill})$ was measured to be $3.9 \mathrm{eV}$, in good agreement with the literature. ${ }^{33}$ For $\mathrm{CH}_{3} \mathrm{I} / \mathrm{D}_{2} \mathrm{O} / \mathrm{Cu}(111)$ and $\mathrm{CH}_{3} \mathrm{I} / \mathrm{Cu}$ (111). the work functions were also measured to be all $3.9 \mathrm{eV}$ $( \pm 0.1 \mathrm{eV})$. The work function was measured using the shift in secondary electron emission cutoff, relative to that of clean $\mathrm{Cu}(\Phi=4.95 \mathrm{eV}) .^{+5}$ as shown in Figure 5 . Because the band gap of ice is $\sim 8 \mathrm{eV}^{23, ? 6}$ much higher energy than the energies

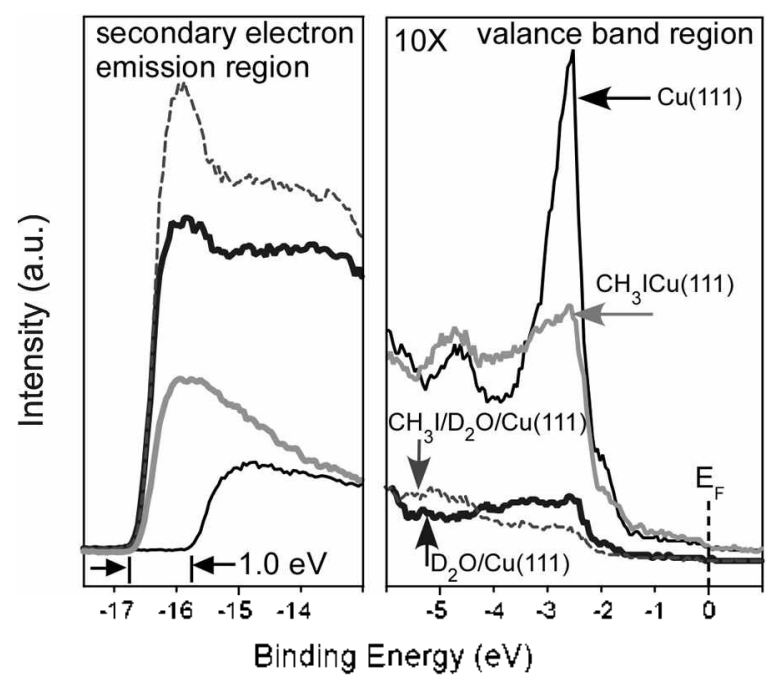

Figure 5. UPS for bare $\mathrm{Cu}(111), \mathrm{CH}_{3} \mathrm{I}(1.0 \mathrm{~L}) / \mathrm{Cu}(111), \mathrm{D}_{2} \mathrm{O}(1.0$ $\mathrm{L} / \mathrm{Cu}(111)$, and $\mathrm{CH}_{3} \mathrm{I}(1.0 \mathrm{~L}) / \mathrm{D}_{2} \mathrm{O}(1.0 \mathrm{~L}) / \mathrm{Cu}(111)$ taken at $100 \mathrm{~K}$. The binding energy is referenced to the Fenmi level $\left(E_{F}\right)$. The vallance band (amplified by $10 \times$ ) region is not discussed in this paper.

(up to $\sim 5 \mathrm{eV}$ ) of photons generated from $\mathrm{Hg}$ lamp. it appears that the electrons photoexcited from the valance band of $\mathrm{Cu}$ transfer to the conduction band of ice to generate solvated electrons in the ice film. The solvated electrons then quickly transfer to $\mathrm{CH}_{3} \mathrm{I}$ to precede the cleavage of $\mathrm{C}-\mathrm{I}$ bond. Ryu et al. found that the lifetime of solvated electrons in $\mathrm{H}_{2} \mathrm{O}$ ice film was a few hundred fentoseconds, and the lifetime was dramatically decreased upon adsorption of $\mathrm{CFCl}_{3}$ on the ice film. They attributed the lifetime decrease to dissociative (scission of $\mathrm{C}-\mathrm{Cl}$ bonds) electron transfer of the electrons to the adsorbate $\mathrm{CFCl}_{3}$.

\section{Summay}

Thermal and photochemistry of $\mathrm{CH}_{3} \mathrm{I}$ dosed on $\mathrm{D}_{2} \mathrm{O}$ ice film grown on $\mathrm{Cu}(111)$ at $100 \mathrm{~K}$ were studied by temperatureprogrammed desorption (TPD) time-of-flight mass spectrometry (TOF-MS), X-ray and ultra-violet photoelectron spectroscopies. On the basis of TPD. $\mathrm{CH}_{3} \mathrm{I}$ desorbs from $\mathrm{D}_{2} \mathrm{O}$ ice layer at 120 and $130 \mathrm{~K}$. attributed to multilayer and monolayer desorptions, respectively. No other reaction products were detected within our instrumental sensitivity. $\mathrm{CH}_{3} \mathrm{I}$ on ice film is dramatically dissociated by photo-irradiation at $100 \mathrm{~K}$. We attribute the enhanced dissociation to solvated electrons in ice film. The electrons are likely the photoexcited electrons transferred from the $\mathrm{Cu}$ substrate. During photo-irradiation at 100 $\mathrm{K}$. the dissociated products $\left(\mathrm{CH}_{2}\right.$ and $\left.\mathrm{I}\right)$ seem to diffuse into ice film by rearrangement (and self-diffusion) of water molecules. The parent $\mathrm{CH}_{3} \mathrm{I}$ may also diffuse into ice film to be solvated (or trapped). indicated by a newly appeared TPD peak at $145 \mathrm{~K}$. No molecular ejection was found during photo-irradiation at $100 \mathrm{~K}$. indicated by no change in C $1 \mathrm{~s}$. Ols. and $\mathrm{I} 3 \mathrm{~d} 5: 2$ XPS intensities. The $\mathrm{CH}_{3}$ and I chenusorb on $\mathrm{Cu}(111)$ during photo-irradiation and/or TPD, indicated by a 15 amu TPD peak at $430 \mathrm{~K}$ and change in I $3 \mathrm{~d}_{5: 2}$ XPS. respectively. For the I $3 \mathrm{~d}_{5 ; 2}$ XPS of $\mathrm{CH}_{3} \mathrm{I}$ on $\mathrm{D}_{2} \mathrm{O}$ ice film at $100 \mathrm{~K}$, the XPS BE shifts to 
lower BEs and the fwhm dramatically changes with increasing photo-irradiation time. For all $\mathrm{CH}_{3} \mathrm{I} / \mathrm{Cu}(1 \mathrm{ll}), \mathrm{D}_{2} \mathrm{O} / \mathrm{Cu}(\mathrm{Ill})$ and $\mathrm{CH}_{3} / \mathrm{D} \mathrm{D}_{2} \mathrm{O} / \mathrm{Cu}(1 \mathrm{ll})$ studied systems. the estimated work function was $3.9( \pm 0.05) \mathrm{eV},-1.0 \mathrm{eV}$ shift from that of $\mathrm{Cu}$ (111).

Acknow ledgments. This work was supported by the Center for Materials Chemistry at the University of Texas at Austin. National Science Foundation (CHE 0412609). and the Robert A. Welch Foundation.

\section{References}

1. Somorai, G. A. Introduction to Surface Chemistry and Catalvsis; Wiley: New York, 1994

2. Bent, B. E. Chem. Rev. 1996, 96, 1361.

3. Ma, Z.; Zaera, F. Surf. Sci. Rep. 2006, 61, 229.

4. Somorjai, G. A.: Park, I. Y. J. Chem. Phvs. 2008, 128, 182504.

5. Faradzhev, N. S.: Peny, C. C.; Kusmierek, D. O.: Fairbrother, D. H.; Madev, T. E. J. Chent. Phus. 2004, 121, 8547.

6. Pery, C. C.; Faradzhev, N. S ; Madey, T. E.; Fairbrother, D. H. J. Chem. Phns. 2007, 126, 204701.

7. Lu, Q.-B.; Sanche, L Phvs. Rev Lett. 2001, 87, 078501.

8. Tachikawa, H. Phys. Chem. Chem. Phys. 2008, 10, 2200.

9. Barone, S. B.: Zondlo, M. A.: Tolbert, M. A.J. Phus. Chem. A $1999,103,9717$
10. Huff, A. K.: Abbatt, J. P. D. J. Phus Chem. $12000,104,7284$.

11. Klan, P.: Holoubek, I. Chemosphere 2002, 46, 1201

12. Garrett, S. J.: Holbert, V. P.: Stair, P. C.: Weitz, E. J. Chem. Phss. $1994,100,4615$.

13. Coon, S. R.: Myli, K. B.; Grassian, V. H. J. Phus. Chem. 1995. 99,16416 .

14. Totir, G. G.: Le, Y.; Osgood, J. R. M. J. Phus. Chem. B 2005. 109,8452 .

15. Zhou, X. L.; White, J. M. Surf. Sci. 1991, 241, 270.

16. Xi, M: Bent, B. E. J. Iac. Sci. Technol. B 1992, 10, 2440.

17. Lin, J.-L.; Bent, B. E. J. Phys. Chent 1993, $97,9713$.

18. Hinch, B. J.; Dubois, L. H. J. Chent. Phys. 1992, 96, 3262.

19. Grecea, M. L.; Backus, E. H. G.; Fraser, H. T.; Pradeep, T.; Kleyn, A. W. Bont, M.; Chem. Phws. Lett. 2004, 385, 244.

20. Soln, Y; Wei, W: White, J. M. Surf. Sci. 2008, 602, 2706.

21. Perr, C. C.; Faradzhev, N. S.; Fairbrother, D. H.; Madey, T. E. Int. Rev in Phus Chem. 2004, 23, 289.

22. Lee, H. M.: Suh, S. B.; Kim, K. S. J. Chem. Phss 2003, 119 . 7685 .

23. Bovensiepen, U.; Gahl, C.; Wolf, M. J. Phus Chem. B 2003, 107. 8706.

24. Gahl, C.: Bovensiepen, U.; Frischkon, C.; Wolf, M. Phus. Rev? Lett. 2002, 89, 107402.

25. Soln, Y.: Wei, W. White, T. M. J. Phus Chem. C 2007, 111,5101.

26. Shibaguchi, T.; Onuki, H.; Onaka, R. J. Phys. Soc. Jpm. 1977, 42 , 152.

27. Ryu, S.; Chang, J ; Kwon, H,; Kim, S. K. J. Am. Chem. Soc. 2006, 128,3500 . 